\title{
产 Increased IgE-dependent mast cell activation and anaphylactic responses in mice lacking the calcium- activated nonselective cation channel TRPM4
}

\author{
Rudi Vennekens ${ }^{1,2}$, Jenny Olausson ${ }^{2}$, Marcel Meissner ${ }^{2}$, Wilhelm Bloch ${ }^{3}$, Ilka Mathar ${ }^{2}$, Stephan E Philipp ${ }^{2}$, \\ Frank Schmitz ${ }^{4}$, Petra Weissgerber ${ }^{2}$, Bernd Nilius ${ }^{1}$, Veit Flockerzi ${ }^{2} \&$ Marc Freichel $^{2}$
}

Mast cells are key effector cells in allergic reactions. Aggregation of the receptor Fc\&RI in mast cells triggers the influx of calcium $\left(\mathrm{Ca}^{2+}\right)$ and the release of inflammatory mediators. Here we show that transient receptor potential TRPM4 proteins acted as calcium-activated nonselective cation channels and critically determined the driving force for $\mathrm{Ca}^{2+}$ influx in mast cells. Trpm4 $4^{-1-}$ bone marrow-derived mast cells had more $\mathrm{Ca}^{2+}$ entry than did TRPM4 $4^{+/+}$cells after Fc\&RI stimulation. Consequently, Trpm4 ${ }^{-/-}$ bone marrow-derived mast cells had augmented degranulation and released more histamine, leukotrienes and tumor necrosis factor. $\operatorname{Trpm}^{-/-}$mice had a more severe IgE-mediated acute passive cutaneous anaphylactic response, whereas late-phase passive cutaneous anaphylaxis was not affected. Our results establish the physiological function of TRPM4 channels as critical regulators of $\mathrm{Ca}^{2+}$ entry in mast cells.

Mast cells are bone marrow-derived hematopoietic cells localized near surfaces exposed to the environment, such as the skin, the airway epithelia and the intestine, where pathogens, allergens and other environmental agents are frequently encountered ${ }^{1}$. Activation and degranulation of mast cells is a key step in the pathogenesis of allergic diseases such as bronchial asthma and systemic anaphylaxis ${ }^{2}$. An allergic reaction develops when allergens encountered by antigen-presenting cells are processed and presented to $\mathrm{T}$ cells. Ensuing $\mathrm{T}$ helper type 2 responses cause $\mathrm{B}$ cells to produce allergen-specific immunoglobulin E (IgE). The $\operatorname{IgE}$ molecules bind to the receptor Fc\&RI on the surfaces of mast cells. After re-exposure to the allergen, FceRI-associated IgE molecules bind allergen and aggregate, thereby activating mast cells. Activated mast cells secrete preformed mediators, including proteases and vasoactive amines, such as histamine, that are stored in cytoplasmic granules. In addition, mast cell activation results in the de novo synthesis of proinflammatory lipid mediators, cytokines and chemokines. The instant release of histamine is crucial for the development of immediate-type allergic reactions that result in vasodilatation, increased vascular permeability and smooth muscle contraction ${ }^{1,2}$. In addition, IgE-dependent mast cell activation may be complemented by signaling cascades triggered by several endogenous ligands, such as adenosine, resulting in the amplification and maintenance of Fc\&RI-mediated degranulation ${ }^{3,4}$.
FceRI crosslinking activates many signaling molecules ${ }^{5,6}$. A chief 'downstream' target is phospholipase C- $\gamma 1$, which catalyzes the hydrolysis of phosphatidylinositol-4,5-bisphosphate to diacylglycerol and inositol-1,4,5-trisphosphate ${ }^{5}$. In contrast, adenosine stimulation involves the activation of $\mathrm{G}_{\alpha \mathrm{i}}$ protein-coupled $\mathrm{A}_{3}$ adenosine receptors in mouse mast cells, which leads to the activation of phospholipase $\mathrm{C}$ and phospholipase $\mathrm{D}$ through $\mathrm{G}_{\beta \gamma}$ protein and phosphatidylinositol$3-\mathrm{OH}$ kinase- $\gamma^{7,8}$. Inositol-1,4,5-trisphosphate and diacylglycerol promote the activation of protein kinase $\mathrm{C}$ and release of calcium $\left(\mathrm{Ca}^{2+}\right)$ from intracellular stores, followed by an influx of $\mathrm{Ca}^{2+}$ from the extracellular space ${ }^{9,10}$ through calcium release-activated calcium (CRAC) channels ${ }^{11}$. $\mathrm{Ca}^{2+}$ influx is indispensable for mast cell activation and degranulation and critically depends on the membrane potential, which provides the driving force for $\mathrm{Ca}^{2+}$ entry ${ }^{12,13}$.

Calcium-activated nonselective cation (CAN) channels were originally described in cultured rat cardiac cells ${ }^{14}$. TRPM4 and TRPM5 have been identified as two unique molecular candidates for the CAN class of ion channels ${ }^{15-17}$. Both proteins belong to the melastatin subfamily of transient receptor potential (TRP) membrane proteins ${ }^{18}$. It has long been suggested that CAN channels might control the membrane potential of cells and thereby control the magnitude of $\mathrm{Ca}^{2+}$ influx. In electrically excitable cells, in which $\mathrm{Ca}^{2+}$ influx is mediated mainly by voltage-gated $\mathrm{Ca}^{2+}$ channels, depolarization would enhance $\mathrm{Ca}^{2+}$ entry. In electrically nonexcitable cells, such as mast cells, in which

\footnotetext{
${ }^{1}$ Laboratory of Ion Channel Research, Division of Physiology, Department of Molecular Cell Biology, Campus Gasthuisberg, 0\&N1, KU Leuven, Herestraat 49 bus 802 , B-3000 Leuven, Belgium. ${ }^{2}$ Experimentelle und Klinische Pharmakologie und Toxikologie, Universität des Saarlandes, D-66421 Homburg, Germany. ${ }^{3}$ Institut für Kreislaufforschung und Sportmedizin, Molekulare und Zelluläre Sportmedizin, Deutsche Sporthochschule, 50927 Köln, Germany. ${ }^{4}$ Anatomisches Institut, Universität des Saarlandes, D-66421 Homburg, Germany. Correspondence should be addressed to R.V. (rudi.vennekens@med.kuleuven.be) or M.F. (marc.freichel@uniklinikum-saarland.de).
} 
a
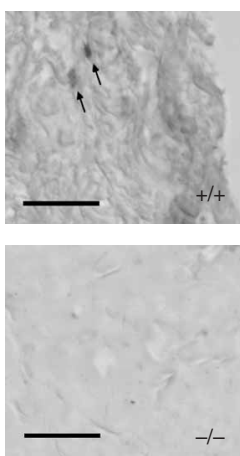
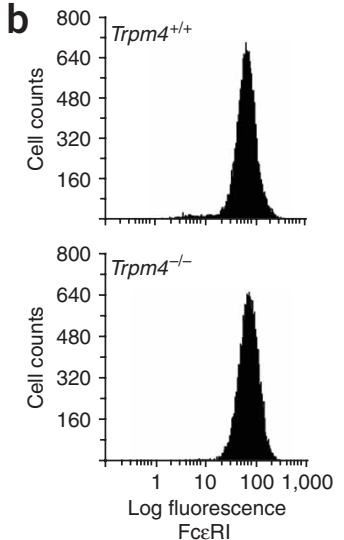

C
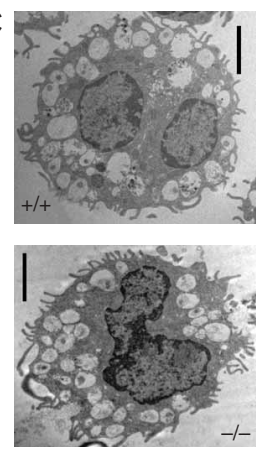
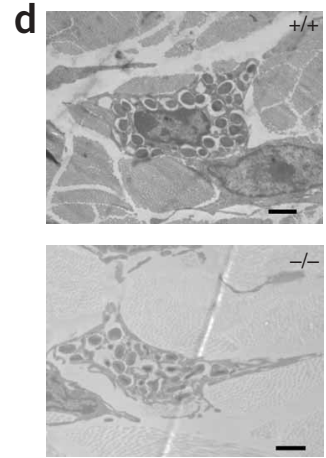
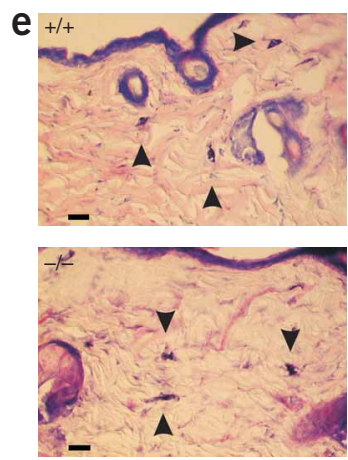

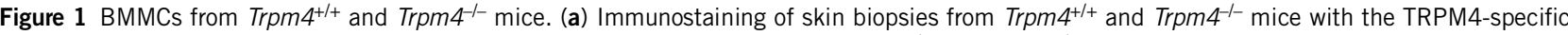
antibody 578. (b) Flow cytometry of FceRI surface expression on BMMCs from Trpm4 $4^{+/+}$and Trpm $4^{-1-}$ mice. (c,d) Ultrastructural analysis of cultured BMMCs (c) and skin biopsies (d) from Trpm4 $4^{+/+}$and Trpm $4^{-/-}$mice. (e) Representative May-Grünwald-Giemsa staining of skin biopsy cross-sections showing the distribution of tissue mast cells (arrowheads) in the skin of $\operatorname{Trpm} 4^{+/+}$and $\operatorname{Trpm} 4^{-/-}$mice. Scale bars, $50 \mu \mathrm{m}(\mathbf{a}), 2 \mu \mathrm{m}(\mathbf{c}, \mathbf{d})$ and $20 \mu \mathrm{m}(\mathbf{e})$

$\mathrm{Ca}^{2+}$ entry occurs through store- or receptor-operated channels, depolarization of the membrane potential would decrease the rate of $\mathrm{Ca}^{2+}$ influx ${ }^{12,19}$. That hypothesis is supported by data from studies of cell lines in which TRPM4 was overexpressed ${ }^{16}$ or TRPM4 function and expression was 'knocked down'20,21.

To test the importance of CAN channels in vivo, we generated TRPM4-deficient (Trpm4 $4^{-1-}$ ) mice. We found that TRPM4 channel activity critically regulated FceRI-induced mast cell $\mathrm{Ca}^{2+}$ influx and activation. Activated Trpm $4^{-1-}$ cells released excessive histamine, leukotrienes and tumor necrosis factor (TNF), and Trpm $4^{-1-}$ mice had a more severe acute anaphylactic response in the skin than did wild-type control mice. In summary, our results indicate that TRPM4 channel activation is an efficient mechanism for limiting antigeninduced mast cell activation in vivo.

\section{RESULTS}

\section{Mast cell development in $\mathrm{Trpm}^{-1-}$ mice}

We inactivated Trpm4 in mouse embryonic stem cells with a Cre-loxPmediated gene-targeting strategy (Supplementary Fig. 1 online). We confirmed recombination and Cre-mediated excision of exons 15 and 16, encoding the first transmembrane segment in TRPM4, which is present in all known TRPM4 splice variants ${ }^{17}$, by Southern blot analysis (Supplementary Fig. 1). Trpm $m 4^{-1-}$ mice were viable and fertile, showed no obvious anatomical abnormalities, and were segregated with the expected mendelian frequency $\left(84 \mathrm{Trpm}^{+/+}, 122\right.$ $\mathrm{Trpm}^{+/-}$and $81 \mathrm{Trpm}^{-{ }^{-1}}$ progeny obtained from 39 litters of heterozygous crosses). Adult Trpm $4^{+/+}$and $\operatorname{Trpm} 4^{-1-}$ mice were of similar size and weight (at 6-10 weeks of age: $\operatorname{Tr} p m 4^{+/+}, 30.7 \pm 0.5 \mathrm{~g}$ $\left(n=14\right.$ mice); Trpm4 ${ }^{-1-}, 30.5 \pm 0.7 \mathrm{~g}(n=14$ mice $\left.) ; P>0.05\right)$. Contrary to what could be anticipated from a published study of a pancreatic $\beta$-cell line $e^{20}$, glucose clearance was identical in $\operatorname{Tr} p m 4^{+/+}$ and $\operatorname{Trpm} 4^{-/-}$mice challenged with intraperitoneal glucose, and glucose-induced insulin release from pancreatic islets remained unchanged after deletion of Trpm4 (Supplementary Fig. 2 online).

Bone marrow-derived mast cells (BMMCs) had high expression of Trpm4 (Supplementary Fig. 2). Correspondingly, comparative RT-PCR analysis indicated that Trpm4 transcripts were abundant in BMMCs, were less abundant in $\mathrm{CD}^{+} \mathrm{CD}^{+} \mathrm{T}$ cells and were not detectable in $\mathrm{CD}^{+} \mathrm{CD}^{+} \mathrm{T}$ cells or $\mathrm{CD} 19^{+} \mathrm{B}$ cells (Supplementary Fig. 2). We did not identify Trpm5 transcripts in any of those cell types. Using a polyclonal antibody directed against the amino termi- nus of TRPM4, we detected 138-kilodalton proteins in BMMCs and pancreatic islets from Trpm $4^{+/+}$but not Trpm $4^{-/-}$mice (Supplementary Fig. 2). Using the same antibody, we detected TRPM4 in connective tissue mast cells of the skin (Fig. 1a) and in $\mathrm{CD}^{+} \mathrm{CD}^{+}$ T cells from Trpm $4^{+/+}$but not Trpm $4^{-/-}$mice (Supplementary Fig. 2). We found no staining of $\mathrm{CD}^{+} \mathrm{CD} 8^{+} \mathrm{T}$ cells or $\mathrm{CD} 19^{+} \mathrm{B}$ cells (data not shown). We also did not detect TRPM4 proteins in Jurkat T cells (data not shown).

Bone marrow from Trpm $4^{+/+}$and Trpm $4^{-/-}$mice generated highly pure mast cell populations (consistently over $95 \%$ purity) in cultures supplied with interleukin 3 (IL-3), as assessed by surface expression of FcERI (Fig. 1b) and c-Kit (data not shown). The morphology of Trpm $4^{-1-}$ mast cells was unaltered compared with that of Trpm $4^{+/+}$ mast cells, as assessed by electron microscopy of BMMC cultures and of connective tissue mast cells in the skin (Fig. 1c,d). Average size, average number of granules (Trpm $4^{+/+}, 33 \pm 2\left(n=52\right.$ cells); $\operatorname{Tr} p m 4^{-/-}$, $36 \pm 2(n=53$ cells $))$ and overall shape were not different for Trpm $4^{-1-}$ versus Trpm $4^{+/+}$mast cells. Furthermore, the density of mast cells in the skin was equal for $\operatorname{Trpm} 4^{-/-}$and $\operatorname{Trpm} 4^{+/+}$mice $\left(\operatorname{Tr} p m 4^{+/+}\right.$, $3.0 \pm 0.8$ cells $/ 0.076 \mathrm{~mm}^{2} ;$ Trpm4 ${ }^{-1-}, 2.7 \pm 1.3$ cells $/ 0.076 \mathrm{~mm}^{2} ; n=3$ individual mice; mean \pm s.d.; $P>0.05$; Fig. 1e). These results collectively indicated that mast cell development is not impaired in the absence of TRPM4.

\section{CAN currents in mouse BMMCs}

To measure CAN currents in mouse BMMCs, we used the patchclamp technique 22,23 . This technique allows the measurement of currents through a single ion channel or many ion channels at the same time, according to the relevant configuration. By comparing the currents of Trpm $4^{-1-}$ and Trpm $4^{+/+}$BMMCs, we were able to establish whether TRPM4 was part of the endogenous CAN channel in BMMCs and were able to compare its electrophysiological properties with those determined in heterologous overexpression experiments. We first recorded currents from Trpm $4^{+/+}$BMMCs (Fig. 2) using the wholecell configuration. We dialyzed cells with a pipette solution containing $10 \mu \mathrm{M}$ free $\mathrm{Ca}^{2+}$. We omitted potassium $\left(\mathrm{K}^{+}\right)$from the recording solutions to avoid the contribution of $\mathrm{K}^{+}$channels to the whole-cell current. In such conditions, a relatively large, stable cation current was activated after a variable delay (20-100 s; Fig. 2a). Inward current was completely blocked by the replacement of extracellular sodium $\left(\mathrm{Na}^{+}\right)$ with the large cation $\mathrm{N}$-methyl-D-glucamine (NMDG), indicating that 
a

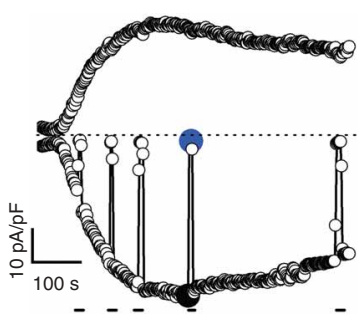

b

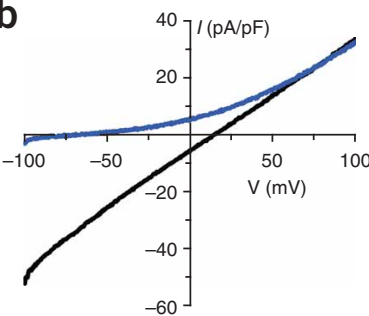

Figure 2 A CAN channel in Trpm4 $4^{+/+}$but not Trpm $4^{-/-}$BMMCs. (a) Time course of the whole-cell current amplitude at $-80 \mathrm{mV}$ and $+80 \mathrm{mV}$ in Trpm4 $4^{+/+}$BMMCs, derived from consecutive voltage ramps from $-100 \mathrm{mV}$ to $+100 \mathrm{mV}\left(V_{\mathrm{H}}=0 \mathrm{mV}\right)$ applied at $0.5 \mathrm{~Hz}$. Dashed line, zero current. Cells were dialyzed with a pipette solution containing $10 \mu \mathrm{M} \mathrm{Ca}^{2+}$. Short horizontal lines below indicate perfusion of the cell with bath solution containing NMDG. Data are from one representative of 35 experiments. (b) Current traces of $\operatorname{Trpm} 4^{+/+}$BMMCs obtained in an experiment as described in a, with standard bath solution (black line) or bath solution containing NMDG (blue line; these correspond to symbol colors in a). Data are from one representative of 35 experiments. (c) Mean current densities of CAN currents at $-80 \mathrm{mV}$ in response to various cytoplasmic experiments. (d) Single-channel openings recorded at $-100 \mathrm{mV}$ from 'inside-out' membrane patches. The cytosolic side was exposed to $300 \mu \mathrm{M} \mathrm{Ca}^{2+}$. Dashed horizontal lines, zero current. Mean single-channel conductance, $25.3 \pm 0.7 \mathrm{pS}$. Data are one representative amplitude histogram of five. $p^{\star} N$, open probability $\times$ number of channels. (e) Time course and current traces of CAN currents in Trpm $4^{-1-}$ BMMCs, as described in $\mathbf{a}$ and $\mathbf{b}$. Data are from one representative of 29 experiments. (f) Mean current densities measured at $-80 \mathrm{mV}$ in Trpm4 ${ }^{+/+}$BMMCs $\left(n=35\right.$ cells) and $\operatorname{Trpm} 4^{-/-}$BMMCs ( $n=29$ cells) as described in a. $P<0.01$

the current was carried by cations. On average, the current density was $55.1 \pm 9.1 \mathrm{pA} / \mathrm{pF}(n=35$ experiments; membrane potential, $-80 \mathrm{mV})$ in $\operatorname{Trpm} 4^{+/+}$BMMCs. The current-voltage relationship $(I-V)$ of currents in wild-type cells was linear and reversed at $+1.4 \pm 0.5 \mathrm{mV}$ in the presence of $\mathrm{Na}^{+}$and was $-94.8 \pm 2.7 \mathrm{mV}$ in the presence of NMDG $(n=35$; Fig. $2 \mathbf{b})$. A series of $400-\mathrm{ms}$ voltage steps between $-100 \mathrm{mV}$ and $+140 \mathrm{mV}$ showed no obvious voltage or time dependence of currents (data not shown). When we compared the mean current densities of cells dialyzed with different $\mathrm{Ca}^{2+}$ concentrations, the $\mathrm{Ca}^{2+}$ dependence of the current was obvious (Fig. 2c). In insideout' patches, we were able to record single-channel activity in the presence of $300 \mu \mathrm{M} \mathrm{Ca}^{2+}$ at the cytosolic side of the membrane. We recorded traces at $-100 \mathrm{mV}$ from three different patches (Fig. 2d). The

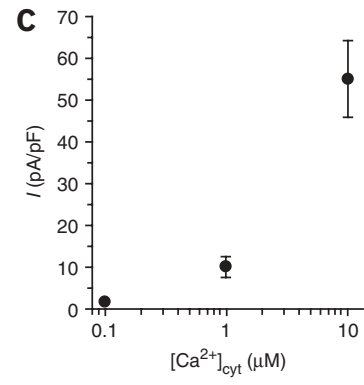

e
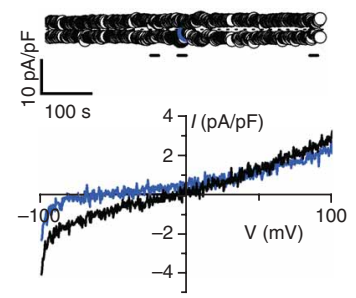

d

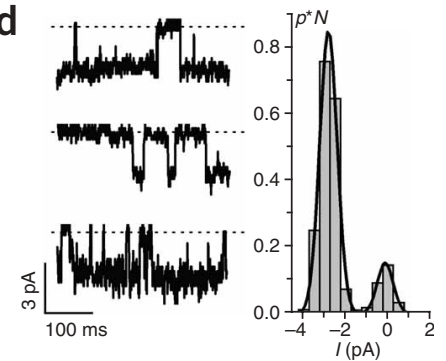

f

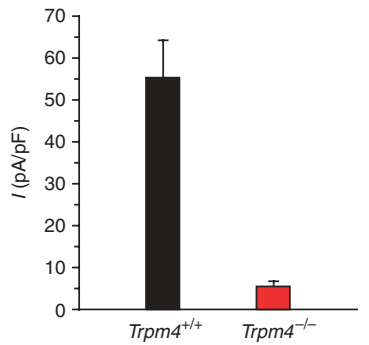

single-channel conductance was $25.3 \pm 0.7 \mathrm{pS}(n=5)$, similar to that of TRPM4 overexpressed HEK293 cells ${ }^{16,17}$. To further characterize the current, we measured the permeability of endogenous TRPM4 for different monovalent cations and $\mathrm{Ca}^{2+}$ (Supplementary Fig. 3 online), which often shows a 'signature' for a specific ion channel. We substituted equimolar amounts of $\mathrm{Li}^{+}, \mathrm{Cs}^{+}$or $\mathrm{NMDG}^{+}$for $\mathrm{Na}^{+}$in the extracellular solution. When we analyzed changes in conductance, we obtained a relative permeability sequence $\left(\mathrm{P}_{\mathrm{X}} / \mathrm{P}_{\mathrm{Na}}\right)$ of $\mathrm{Na}^{+}>\mathrm{Cs}^{+}>$ $\mathrm{Li}^{+}>>\mathrm{NMDG}^{+}$, which is identical to the permeability sequence of TRPM4 overexpressed in HEK293 cells ${ }^{24}$. To assess $\mathrm{Ca}^{2+}$ permeability, we replaced extracellular $\mathrm{NaCl}$ with $100 \mathrm{mM} \mathrm{CaCl}_{2}$. We detected no substantial inward currents even at very negative membrane potentials.
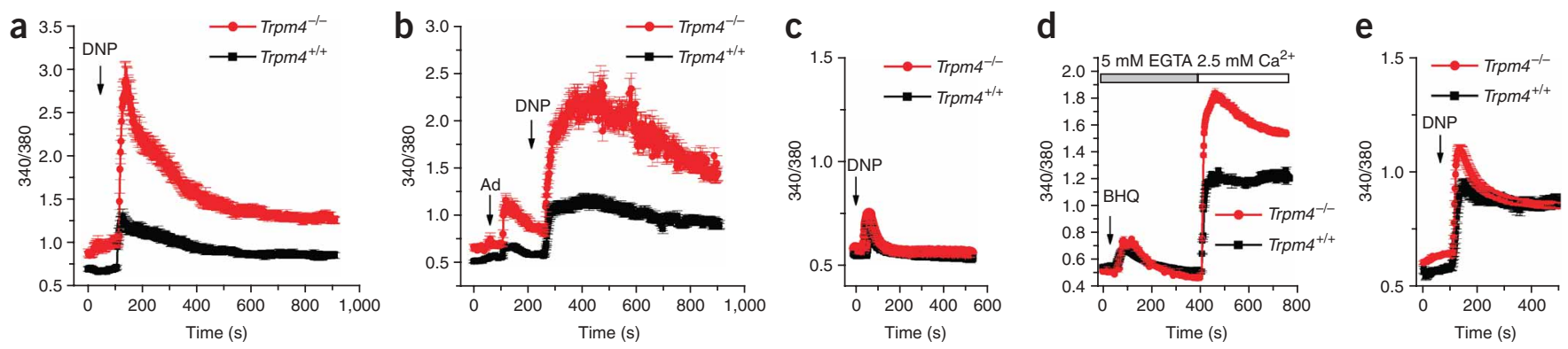

Figure $3 \mathrm{Ca}^{2+}$ signaling in Trpm $4^{+/+}$and $\operatorname{Trpm} 4^{-/-}$BMMCs. Mean traces for the time-dependent change in $\left[\mathrm{Ca}^{2+}\right]_{\mathrm{cyt}}$ in Fura-2-loaded Trpm4 $4^{+/+}$and $\operatorname{Trpm} 4^{-/-}$ BMMCs are presented as the ratio of fluorescence at $340 \mathrm{~nm}$ to that at 380 (340/380). All $n$ values represent the number of individual cells, pooled from at least three independent experiments. (a) Averaged time course of $\left[\mathrm{Ca}^{2+}\right]_{\mathrm{cyt}}$ after the application of DNP-HSA (DNP; $100 \mathrm{ng} / \mathrm{ml}$ ) to Trpm4 ${ }^{+/+} \mathrm{BMMCs}$ $(n=77)$ and $\operatorname{Trpm}^{-/-}$BMMCs $(n=66)$ pretreated with IgE anti-DNP-HSA. $P<0.01$. (b) Averaged time course of $\left[\mathrm{Ca}^{2+}\right]_{\mathrm{cyt}}$ after the application of adenosine (Ad; $10 \mu \mathrm{M})$ followed by DNP-HSA $(100 \mathrm{ng} / \mathrm{ml})$ to Trpm $4^{+/+}$BMMCs $(n=66)$ and $\operatorname{Trpm} 4^{-/}$BMMCs $(n=100)$ pretreated with IgE anti-DNP-HSA. $P<0.01$. (c) Averaged time course of $\left[\mathrm{Ca}^{2+}\right]_{\text {cyt }}$ after stimulation of IgE-pretreated Trpm $4^{+/+}$BMMCs $(n=108)$ and Trpm $4^{-/-}$BMMCs $(n=95)$ as described in $\mathbf{a}$ in the absence of extracellular $\mathrm{Ca}^{2+} . P>0.05$. (d) Averaged time course of $\left[\mathrm{Ca}^{2+}\right]_{\mathrm{cyt}}$ in $\operatorname{Trpm} 4^{+/+} \mathrm{BMMCs}(n=107)$ and $\operatorname{Trpm} 4^{-1-} \mathrm{BMMCs}$ $(n=108)$ after depletion of intracellular $\mathrm{Ca}^{2+}$ stores with $\mathrm{tBHQ}(20 \mu \mathrm{M})$ in $\mathrm{Ca}^{2+}$-free solution and the subsequent addition of $2.5 \mathrm{mM} \mathrm{Ca}{ }^{2+}$ bath solution. $P<0.01$. (e) Averaged time course of $\left[\mathrm{Ca}^{2+}\right]_{\mathrm{cyt}}$ after stimulation of IgE-pretreated $\operatorname{Trpm} 4^{+/+} \mathrm{BMMCs}(n=112)$ and $\operatorname{Trpm} 4^{-/-} \mathrm{BMMCs}(n=125)$ as described in a with extracellular $\mathrm{Na}^{+}$replaced with $\mathrm{K}^{+} . P>0.05$. 


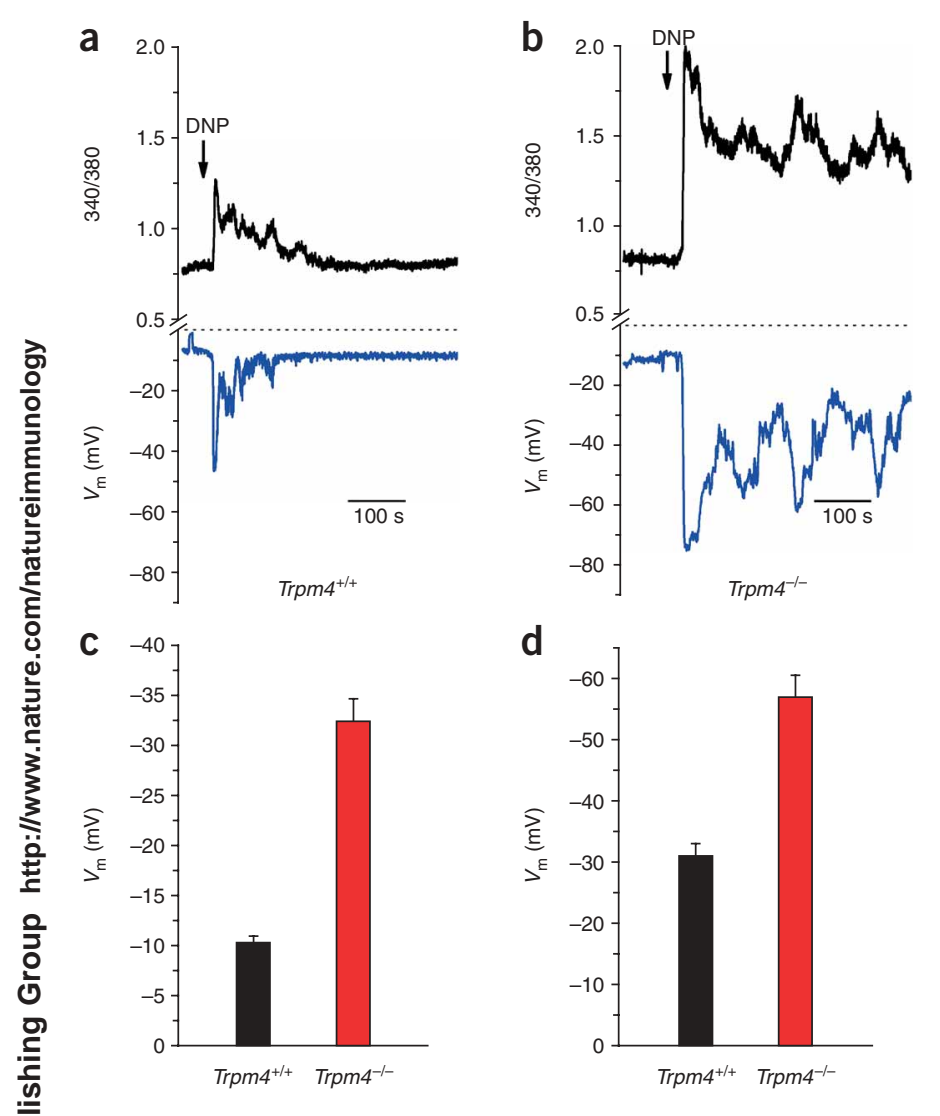

In contrast to Trpm $4^{+/+}$BMMCs, in identical whole-cell conditions, Trpm4 ${ }^{-/-}$BMMCs developed no noteworthy current for at least 10 min. Only a small $\mathrm{Ca}^{2+}$-independent background current was active (Fig. 2e), with a current density of $5.4 \pm 1.1 \mathrm{pA} / \mathrm{pF}(n=29)$ at $-80 \mathrm{mV}$ (Fig. 2f). The $I-V$ curve was linear and reversed at $+1.3 \pm$ $0.3 \mathrm{mV}$ in the presence of $\mathrm{Na}^{+}$and was $-95.9 \pm 3.2 \mathrm{mV}$ in the presence of NMDG $(n=29)$. Currents measured in these conditions had a cation conductance sequence of $\mathrm{Li}^{+}>\mathrm{Na}^{+}>\mathrm{Cs}^{+}>>\mathrm{NMDG}^{+}$, unlike the $\operatorname{Trpm} 4^{+/+}$current described above (Supplementary Fig. 3).

\section{Enhanced $\mathrm{Ca}^{2+}$ entry in Trpm4 ${ }^{-1-}$ BMMCs}

Physiologically relevant activation of mast cells occurs through IgEmediated crosslinking of FcERI ${ }^{2}$, which can be complemented by other endogenous inflammatory ligands, including adenosine, which renders mast cells hyper-reactive to allergen-IgE complexes ${ }^{25,26}$. We incubated BMMCs overnight with dinitrophenyl (DNP)-specific IgE molecules and challenged the cells with the multivalent antigen DNPhuman serum albumin (DNP-HSA), with or without prestimulation with adenosine. Stimulating mast cells with $0.05-0.1 \mathrm{ng} / \mathrm{ml}$ of DNPHSA elicited, after a variable delay, an increase in the cytoplasmic concentration of $\mathrm{Ca}^{2+}\left(\left[\mathrm{Ca}^{2+}\right]_{\text {cyt }}\right)$, which was mostly sustained but did not occur in $100 \%$ of the cells (data not shown). In contrast, treatment with $10 \mathrm{ng} / \mathrm{ml}$ to $1 \mu \mathrm{g} / \mathrm{ml}$ of DNP-HSA triggered a sharp and almost synchronized increase in $\left[\mathrm{Ca}^{2+}\right]_{\mathrm{cyt}}$ in all cells, which was sustained for up to $10 \mathrm{~min}$ (data not shown). In resting conditions, the fluorescence ratio showed some variability between cell preparations, but it was not significantly different for Trpm $4^{+/+}$versus Trpm $4^{-/-}$mast cells when we analyzed all experiments $\left(\operatorname{Trpm} 4^{+/+}, 0.53 \pm 0.11(n=15)\right.$; $\operatorname{Trpm} 4^{-/-}$, $0.6 \pm 0.15(n=16) ; P=0.2)$. When we stimulated BMMCs derived from Trpm $4^{+/+}$and Trpm $4^{-/-}$mice with $100 \mathrm{ng} / \mathrm{ml}$ of DNP-HSA, we detected a sharp increase in $\left[\mathrm{Ca}^{2+}\right]_{\mathrm{cyt}}$ followed by a decrease, until a
Figure 4 Simultaneous measurement of membrane potential and $\left[\mathrm{Ca}^{2+}\right]_{\mathrm{cyt}}$ in Trpm $4^{+/+}$and Trpm $4^{-/-}$BMMCs. Measurements were made in the whole-cell current-clamp mode with perforated patches. $(\mathbf{a}, \mathbf{b})$ Simultaneous measurement of $\left[\mathrm{Ca}^{2+}\right]_{\mathrm{cyt}}$ (presented as in Fig. 3 340/380) and membrane potential $\left(V_{\mathrm{m}}\right)$ of single Trpm $4^{+/+}$BMMCs (a) and Trpm $4^{-/}$BMMCs (b) pretreated with IgE anti-DNP-HSA IgE and challenged with DNP-HSA $(100 \mathrm{ng} / \mathrm{ml})$. Data are one representative of nine experiments each. $(\mathbf{c}, \mathbf{d})$ Pooled data for mean membrane potential during 10 min of measurement after stimulation with $100 \mathrm{ng} / \mathrm{ml}$ of DNP-HSA (Trpm4 $4^{+/+}, n=19$; $\operatorname{Trpm}^{H^{--}}, n=15 ; P<0.01$ ) (c) or with $10 \mu \mathrm{M}$ adenosine plus $100 \mathrm{ng} / \mathrm{ml}$

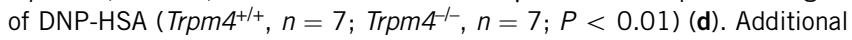
information is in Supplementary Figure 6

plateau was reached (Fig. 3a). Trpm $4^{-/-}$BMMCs had a higher $\left[\mathrm{Ca}^{2+}\right]_{\mathrm{cyt}}$ than did Trpm $4^{+/+}$BMMCs both during the peak and the plateau phase. We obtained similar results when we stimulated BMMCs with $10 \mu \mathrm{M}$ adenosine plus DNP-HSA (Fig. 3b). The increased $\left[\mathrm{Ca}^{2+}\right]_{\mathrm{cyt}}$ was sustained for up to $3 \mathrm{~h}$ after mast cell activation. At $6 \mathrm{~h}$ after receptor activation, we detected prestimulation $\left[\mathrm{Ca}^{2+}\right]_{\mathrm{cyt}}$ in mast cells of each genotype in both conditions (data not shown).

Cytosolic $\mathrm{Ca}^{2+}$ accumulates in response to DNP-HSA and adenosine stimulation is almost entirely due to influx of $\mathrm{Ca}^{2+}$ from the extracellular space, through the CRAC entry channel ${ }^{11}$. In the absence of $\mathrm{Ca}^{2+}$ in the extracellular medium, the response to DNP-HSA (Fig. 3c) and combined stimulation with adenosine and DNP-HSA (Supplementary Fig. 4 online) was limited to a transient peak, representing release of $\mathrm{Ca}^{2+}$ from the intracellular $\mathrm{Ca}^{2+}$ stores, which was not different for Trpm $4^{+/+}$and Trpm $4^{-1-}$ cells. To test whether the increased $\mathrm{Ca}^{2+}$ influx was also apparent after FceRI-independent stimulation, we induced $\mathrm{Ca}^{2+}$ influx using the store-depleting agent 'tBHQ' (2,5-di-(tert-butyl)-1,4-hydroquinone; Fig. 3d). Initial application of $20 \mu \mathrm{M}$ tBHQ in the absence of extracellular $\mathrm{Ca}^{2+}$ elicited a transient peak in $\left[\mathrm{Ca}^{2+}\right]_{\text {cyt }}$ due to leakage of $\mathrm{Ca}^{2+}$ from intracellular stores. Subsequent addition of $2.5 \mathrm{mM}$ extracellular $\mathrm{Ca}^{2+}$ induced a large stable increase in $\left[\mathrm{Ca}^{2+}\right]_{\text {cyt }}$, due to $\mathrm{Ca}^{2+}$ influx from the outside medium, which was again larger for Trpm $4^{-1-}$ than $\operatorname{Trp} m 4^{+/+}$BMMCs. We obtained similar results with $2 \mu \mathrm{M}$ ionomycin (data not shown).

CAN channels may be involved in modulating $\mathrm{Ca}^{2+}$ entry after activation, as an influx of monovalent cations into the cell will depolarize the membrane potential and decrease the driving force for $\mathrm{Ca}^{2+}$ entry ${ }^{19}$. To determine whether such a principle applies to BMMCs, we did experiments similar to those described above, in the presence of $156 \mathrm{mM} \mathrm{K}^{+}$in the extracellular solution. That effectively 'clamped' the membrane potential of Trpm $4^{+/+}$and Trpm $m 4^{-/-}$BMMCs close to $0 \mathrm{mV}$ (Supplementary Fig. 4). In these conditions, considerably less $\mathrm{Ca}^{2+}$ accumulated in response to receptor stimulation in Trpm $4^{+/+}$and Trpm $4^{-/-}$BMMCs than in the conditions described above, after stimulation with DNP-HSA (Fig. 3e) and with adenosine plus DNP-HSA (Supplementary Fig. 4). Notably, except for the first few seconds after stimulation, there was no longer a substantial difference in $\mathrm{Ca}^{2+}$ accumulation for Trpm $4^{+/+}$versus Trpm $4^{-/-}$BMMCs. Because the amplitude of the CRAC current and the phosphorylation of phospholipase C- $\gamma 1$ and phospholipase C- $\gamma 2$ and the kinases p38 and Akt up to 5 min after FceRI stimulation (Supplementary Fig. 5 online) were similar for Trpm $4^{+/+}$and Trpm $4^{-/-}$BMMCs, this suggested that only a difference in the driving force for $\mathrm{Ca}^{2+}$ entry accounted for the greater $\mathrm{Ca}^{2+}$ accumulation in Trpm4 $4^{-1-}$ BMMCs.

\section{Membrane potential in stimulated BMMCs}

To further investigate the last hypothesis proposed above, we measured the membrane potential of BMMCs after receptor stimulation using the current-clamp mode of the patch-clamp technique. We used 
a

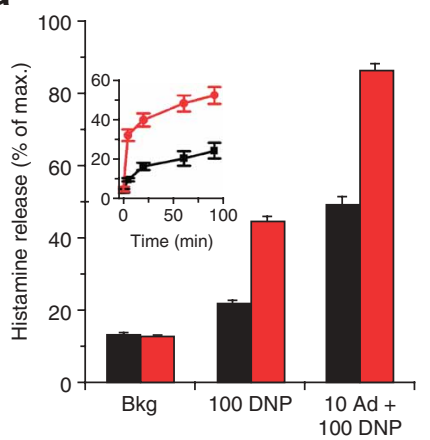

b

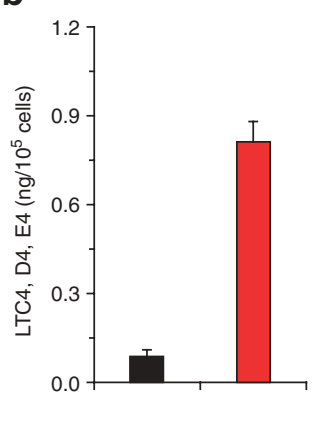

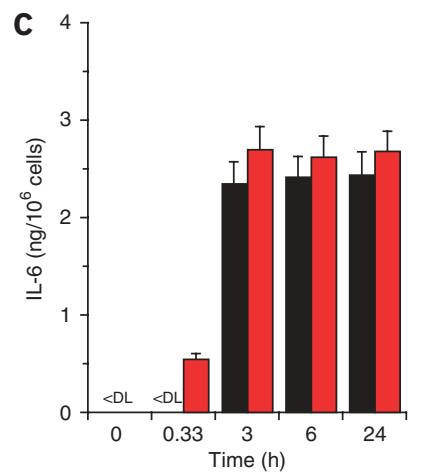

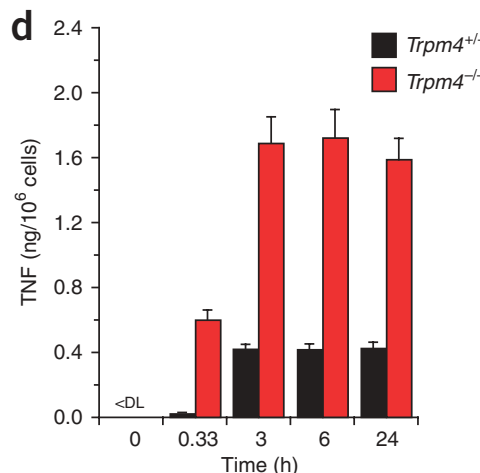

Figure 5 Release of mediators from Trpm $4^{+/+}$and Trpm4 $4^{-/-}$BMMCs. All ' $n$ ' values indicate the number of individual experiments. (a) Averaged histamine release from Trpm $4^{+/+}$and $\operatorname{Trpm} 4^{-/}$BMMCs pretreated with IgE anti-DNP-HSA without stimulation (background $(\mathrm{Bkg}) ; \operatorname{Trpm} 4^{+/+}, n=34 ; \operatorname{Trpm} 4^{-/-}, n=45$ ) or at $20 \mathrm{~min}$ after stimulation with DNP-HSA alone (100 ng/ml (100 DNP); Trpm $\left.4^{+/+} n=50 ; \operatorname{Trpm} 4^{-/-}, n=62\right)$ or with adenosine (10 $\mu$ M) plus DNP-HSA $\left(100 \mathrm{ng} / \mathrm{ml}(10 \mathrm{Ad}+100 \mathrm{DNP}) ; \operatorname{Trpm}^{+/+}, n=49 ; \operatorname{Trpm}^{-/}, n=69\right)$. Inset, averaged histamine release at various times (horizontal axis) after stimulation with DNP-HSA (100 ng/ml; $n=8$, Trpm $4^{+/+}$and Trpm $4^{-/-}$). (b) Secretion, $1 \mathrm{~h}$ after treatment, of leukotrienes $\mathrm{C}_{4}$, $\mathrm{D}_{4}$ and $\mathrm{E}_{4}$ (LTC4, D4, E4) from Trpm4 $4^{+/+}$ mast cells $(n=10)$ and $T r p m 4^{-1-}$ mast cells $(n=10)$ pretreated with IgE anti-DNP-HSA and stimulated with DNP-HSA $(100 \mathrm{ng} / \mathrm{ml}) . P<0.01$. (c,d) Secretion of IL-6 (c) and TNF (d; $P>0.05)$ from Trpm4 $4^{+/+}$and Trpm4 $4^{-/}$BMMCs pretreated with IgE anti-DNP-HSA and stimulated with DNP-HSA $\left(100 \mathrm{ng} / \mathrm{ml}\right.$ ) for various times (horizontal axes); $n=12, \operatorname{Trpm} 4^{+/+}$and $\operatorname{Trpm} 4^{-1-}(\mathbf{c}$ and d). $<\mathrm{DL}$, below detection limit.

perforated patches to preserve cell integrity. Before the application of DNP-HSA to sensitized BMMCs, the membrane potentials of $\operatorname{Trpm}^{+/+}$and Trpm $4^{-/-}$BMMCs were not different $\left(\operatorname{Trpm} 4^{+/+}\right.$, $-27 \pm 3 \mathrm{mV}(n=26$ cells $) ; \operatorname{Trpm} 4^{-/-},-26 \pm 4 \mathrm{mV}(n=21$ cells $)$; $P=0.2)$. We simultaneously measured membrane potential and $\left[\mathrm{Ca}^{2+}\right]_{\mathrm{cyt}}$ after stimulating mast cells with $100 \mathrm{ng} / \mathrm{ml}$ of DNP-HSA and found that the $\left[\mathrm{Ca}^{2+}\right]_{\mathrm{cyt}}$ mirrored the membrane potential changes (Fig. 4a,b). After being stimulated with $100 \mathrm{ng} / \mathrm{ml}$ of DNP-HSA, wildtype BMMCs showed a short hyperpolarization, followed by a rapid and sustained depolarization (19 of 19 cells; see Supplementary Fig. 6 online). In contrast, Trpm $4^{-1-}$ BMMCs showed sustained hyperpolarization ( 6 of 15 cells) or membrane potential oscillations ( 9 of 15 cells). We obtained similar results for stimulation with $10 \mu \mathrm{M}$ adenosine plus $100 \mathrm{ng} / \mathrm{ml}$ of DNP-HSA. Trpm $4^{+/+}$BMMCs reacted to adenosine stimulation with a short hyperpolarization, and subsequent DNP-HSA stimulation triggered either oscillations (4 of 7 cells) or a sustained depolarization (3 of 7 cells; Supplementary Fig. 6). After adenosine stimulation, Trpm $4^{-/}$BMMCs showed a hyperpolarization of the membrane potential that was sustained ( 4 of 7 cells) or was followed by very fast oscillations (3 of 7 cells) after subsequent DNP-HSA stimulation. Compared with Trpm $4^{+/+}$BMMCs, Trpm $4^{-1-}$ BMMCs showed a greater mean hyperpolarization after BMMC activation, as measured by averaging of the membrane potential for $10 \mathrm{~min}$ after the application of DNP-HSA or adenosine plus DNP-HSA (Fig. 4c,d), indicating that in both conditions the driving force for $\mathrm{Ca}^{2+}$ entry was much larger for Trpm $m 4^{-/-}$BMMCs than for Trpm $4^{+/+}$BMMCs after receptor stimulation. Because the amplitude of other ion currents that can determine the membrane potential of activated mast cells (such as calcium-activated potassium currents and calcium-activated chloride currents $^{27}$ ) was not different for Trpm $4^{-/-}$and Trpm $4^{+/+}$BMMCs (Supplementary Fig. 7 online), our results establish an essential function for TRPM4 in membrane potential regulation after FceRI activation. Given our results, we propose the model of ion channel activity and membrane potential regulation after FceRI stimulation in Supplementary Figure 7.

\section{Antigen-induced mediator release from BMMCs}

FceRI-mediated BMMC activation leads to the rapid secretion of preformed inflammatory mediators such as histamine and the de novo synthesis of arachidonic acid metabolites and various cytokines and chemokines $^{2}$. To determine whether the absence of TRPM4 influences BMMC function, we measured the release of histamine, lipid-derived mediators leukotriene $\mathrm{C}_{4}$, leukotriene $\mathrm{D}_{4}$ and leukotriene $\mathrm{E}_{4}$ and the cytokines IL-6 and TNF from Trpm $4^{-/-}$and Trpm $4^{+/+}$BMMCs after FceRI stimulation (Fig. 5). The total histamine content (Trpm $4^{-1-}$ $\operatorname{Trpm}^{+/+}, 0.97 \pm 0.14 ; n=133$ cells) and spontaneous background release of histamine were not different for $\operatorname{Trpm} 4^{-/-}$and $\operatorname{Trpm} 4^{+/+}$ BMMCs (Fig. 5a). However, after being challenged for $20 \mathrm{~min}$ with $100 \mathrm{ng} / \mathrm{ml}$ of DNP-HSA, Trpm4 ${ }^{-/-}$BMMCs released significantly more histamine than did Trpm $4^{+/+}$BMMCs $(P<0.01)$. Similarly, Trpm $4^{-1-}$ BMMCs released more histamine after being stimulated with adenosine $(10 \mu \mathrm{M})$ plus DNP-HSA $(100 \mathrm{ng} / \mathrm{ml})$ or after being stimulated with $2 \mu \mathrm{M}$ ionomycin (Fig. 5a and data not shown). The increased histamine release from Trpm $4^{-1-}$ BMMCs was also obvious after stimulation for shorter or longer time periods (Fig. 5a, inset). Histamine release from BMMCs is dependent on the influx of $\mathrm{Ca}^{2+}$ from the extracellular medium. In the absence of extracellular $\mathrm{Ca}^{2+}$, Trpm $4^{+/+}$and Trpm4 $4^{-/-}$BMMCs had similar release histamine $\left(\operatorname{Trpm} 4^{+/+}, 9.3 \% \pm 0.9 \%(n=8\right.$ cells $) ; \operatorname{Trpm} 4^{-1-}, 11.4 \% \pm 0.6 \%$ $(n=8$ cells $)$ ), which was not significantly different from the spontaneous histamine release $(P>0.05)$. No significant difference was apparent for histamine release from Trpm $4^{+/+}$and Trpm $4^{-1-}$ BMMCs when the membrane potential was clamped close to $0 \mathrm{mV}$ in medium containing $156 \mathrm{mM} \mathrm{K}^{+}\left(\operatorname{Trpm}^{+/+}, 25.0 \% \pm 1.3 \%(n=8\right.$ cells); $\operatorname{Tr} p m 4^{-1-}, 28.5 \% \pm 0.9 \%(n=8$ cells $\left.) ; P>0.05\right)$. To rule out any nonspecific aberration in the exocytosis machinery in Trpm $4^{-1-}$ BMMCs, which might cause increased histamine release independently of increased $\mathrm{Ca}^{2+}$ influx, we measured the capacitance of BMMCs during the perfusion of mast cells with GTP- $\gamma-S$. Intracellular dialysis of mast cells with GTP- $\gamma$-S induces the calcium-independent fusion of histamine-containing vesicles with the plasma membrane ${ }^{28}$. The resulting increase in plasma membrane surface can be accurately measured as an increase in membrane capacitance, which can be monitored with the whole-cell patch-clamp technique ${ }^{29}$. This GTP- $\gamma$ $S$-induced increase in membrane capacitance was not significantly different for wild-type and TRPM4-deficient mast cells $(P>0.05$; Supplementary Fig. 8 online), indicating that exocytosis itself is not affected by the disruption of Trpm4. Trpm $4^{-/-}$BMMCs produced 
a

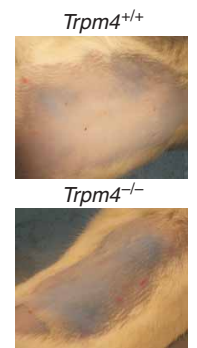

C

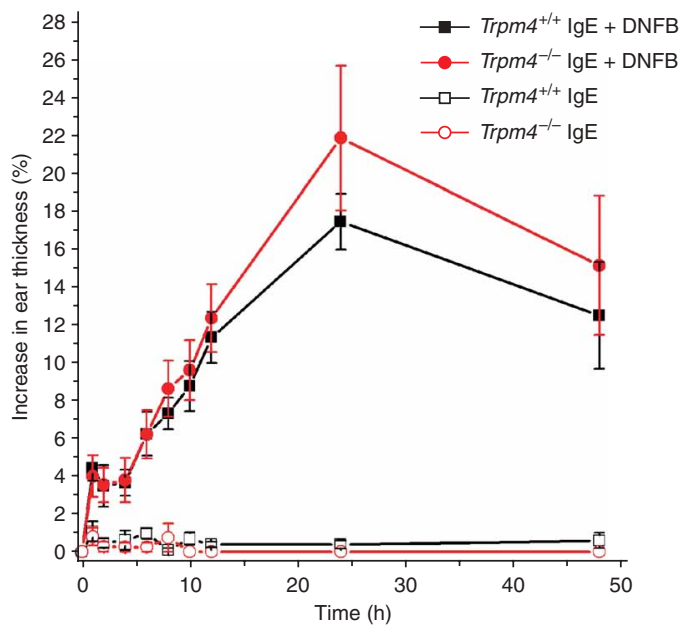

significantly more leukotriene $\mathrm{C}_{4}$, leukotriene $\mathrm{D}_{4}$ and leukotriene $\mathrm{E}_{4}$ than did $T r p m 4^{+/+}$BMMCs when stimulated with $100 \mathrm{ng} / \mathrm{ml}$ of DNP-HSA $(P<0.01$; Fig. 5b). However, the release of IL-6 was not different for $\operatorname{Trpm} 4^{+/+}$and $\operatorname{Trpm} 4^{-/-}$BMMCs at various time points up to $24 \mathrm{~h}$ after stimulation, except at $20 \mathrm{~min}$ after receptor stimulation (Fig. 5c). In contrast, Trpm $4^{-/-}$BMMCs released significantly more TNF than $\operatorname{did} \operatorname{Trpm} 4^{+/+}$BMMCs at all time points up to $24 \mathrm{~h}$ after FceRI stimulation $(P<0.01$; Fig. 5d). The production and release of both IL- 6 and TNF was critically dependent on extracellular $\mathrm{Ca}^{2+}$ influx, as in the absence of extracellular $\mathrm{Ca}^{2+}$, neither mediator was released in measurable quantities (data not shown). When we did the same experiments in medium containing $156 \mathrm{mM} \mathrm{K}^{+}$, much less of each mediator was released $6 \mathrm{~h}$ after stimulation, but there was no longer a difference between $\operatorname{Trpm} 4^{+/+}$and Trpm $4^{-/-}$BMMCs (TNF, $56.8 \pm 5.3 \mathrm{pg}$ per $1 \times 10^{6} \mathrm{Trpm}^{+/+}$cells $(n=3)$ and $61.2 \pm 2.8$ pg per $1 \times 10^{6} \mathrm{Trpm}^{-/-}$ cells $(n=3)$; IL-6, $424.7 \pm 12.3$ pg per $1 \times 10^{6} \mathrm{Trpm}^{+/+}$cells $(n=3)$ and $446.4 \pm 15.7$ pg per $1 \times 10^{6} \operatorname{Trpm}^{-1-}$ cells $\left.(n=3)\right)$. As an additional control, we measured TNF release triggered by stimulation with lipopolysaccharide, which occurs by a calciumindependent pathway ${ }^{30,31}$; lipopolysaccharide-induced release of TNF was not different for Trpm $4^{+/+}$and Trpm $4^{-/-}$BMMCs (Supplementary Fig. 8).

\section{Enhanced acute anaphylactic response in $\mathrm{Trpm} 4^{-1-}$ mice}

To test whether the alterations in FceRI-mediated activation of Trpm4 ${ }^{-/}$BMMCs were relevant for connective tissue mast cells in vivo, we did two types of experiments with passive cutaneous anaphylaxis (PCA) addressing both immediate- and late-phase anaphylactic responses. For the immediate response, at $2 \mathrm{~d}$ after intradermal sensitization with IgE antibody to DNP-HSA (antiDNP-HSA; $60 \mathrm{ng}$ ) or saline injection as a control, we induced PCA by intravenous injection of DNP-HSA dissolved in saline containing

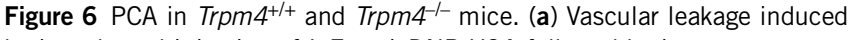
by intradermal injection of IgE anti-DNP-HSA followed by intravenous injection of DNP-HSA together with Evans blue. Images show the skin of the whole back, after shaving, of either a $\operatorname{Trpm}^{4^{+/+}}$or a $\operatorname{Trpm} 4^{-/}$mouse. They were taken using a standard digital camera, without substantial magnification. (b) Vascular leakage of Evans blue dye into skin tissue as a measure of immediate-phase PCA, quantified as the absorbance at $620 \mathrm{~nm}$ $\left(A_{620}\right)$ of fluid extracted from a tissue sample obtained from around the injection site of IgE anti-DNP-HSA (IgE; Trpm $4^{+/+}, n=18$ samples; Trpm4 $4^{-/}, n=22$ samples) or $0.9 \% \mathrm{NaCl}$ (Control; Trpm4 $4^{+/+}, n=19$ samples; $\operatorname{Trpm} 4^{-/-}, n=28$ samples) on the back skin of $\operatorname{Trpm} 4^{+/+}$and Trpm $4^{-1-}$ mice; two skin biopsies per individual mouse were assessed. ${ }^{*}, P<0.01 ;{ }^{*}, P<0.05$. (c) Late-phase PCA. DNFB was topically applied to the right ears of $\operatorname{Trpm} 4^{+/+}$mice $\left(n=8\right.$ mice) and $\operatorname{Trpm} 4^{-/-}$mice ( $n=9$ mice) passively sensitized with IgE anti-DNP-HSA; untreated left ears serve as control ( $\operatorname{Trpm}_{4}^{+/+}, n=8$ mice; $\operatorname{Trpm}^{-{ }^{--}}, n=3$ mice). Data represent the percent increase in ear thickness.

Evans blue. During the first hour after induction, the PCA reaction is mainly dependent on the degranulation of activated mast cells, with rapid histamine and serotonin release, resulting in locally increased blood vessel permeability and the extravasation of Evans blue dye into the surrounding tissue ${ }^{32}$. In control conditions, dye extravasation at $1 \mathrm{~h}$ after the antigen stimulus was the same in $\operatorname{Trpm} 4^{+/+}$and $\operatorname{Tr} p m 4^{-/-}$ skin biopsies. However, after sensitization with IgE anti-DNP-HSA, Trpm $4^{-/-}$mice had much more extravasation of Evans blue into the skin after DNP-HSA injection than did $\operatorname{Trpm} 4^{+/+}$mice (Fig. 6a,b). These data were indicative of increased vascular permeability and more severe cutaneous anaphylaxis in $\operatorname{Trpm} 4^{-/-}$mice. We obtained similar results with a second group of mice that received $30 \mathrm{ng}$ IgE intradermally (data not shown). The density of mast cells before DNPHSA stimulation was not different in the skin of $\operatorname{Trpm} 4^{+/+}$and Trpm $4^{-/-}$mice sensitized with IgE anti-DNP-HSA $\left(\operatorname{Trp} m 4^{+/+}, 2.8 \pm\right.$ 0.8 cells per $0.076 \mathrm{~mm}^{2}$; Trpm $4^{-/-} 2.1 \pm 0.2$ cells per $0.076 \mathrm{~mm}^{2}$; $n=4$ mice; mean \pm s.d.; $P>0.05$ ).

To investigate the late-phase reaction, we sensitized mice by intravenous injection of IgE anti-DNP-HSA and assessed PCA by measuring ear thickness up to $48 \mathrm{~h}$ after epicutaneous application of the hapten 2,4-dinitrofluorobenzene on the ears ${ }^{33}$. Studies in mast cell-deficient ' $\mathrm{W} / \mathrm{W}^{\mathrm{v}}$ ' mice have shown that mast cells are required for both the tissue swelling response and the neutrophil infiltration associated with late-phase IgE-dependent $\mathrm{PCA}^{34}$. We found no difference at any time point for $\operatorname{Tr} p m 4^{+/+}$and $\operatorname{Tr} p m 4^{-/-}$mice (Fig. 6c). These results indicated that TRPM4 is a key determinant of the immediate passive cutaneous anaphylactic response but does not have a 'decisive' function in the development of the latephase reaction.

\section{DISCUSSION}

Here we have established TRPM4 as a key regulator of IgE-mediated $\mathrm{Ca}^{2+}$ entry, BMMC activation and immediate-type allergic reactions in mice. We have identified 138-kilodalton TRPM4 proteins in BMMCs, have shown that TRPM4 is an essential constituent of the endogenous CAN channel in BMMCs and have provided direct experimental evidence, in the form of simultaneous recordings of membrane potentials and intracellular $\mathrm{Ca}^{2+}$ concentrations, that TRPM4 currents are essential determinants of the membrane potential and $\mathrm{Ca}^{2+}$ influx and, consequently, release of proinflammatory mediators induced by antigen stimulation. Finally, we extended the relevance of our results obtained in BMMCs to tissue mast cells of the skin, documenting an enhanced acute IgE-mediated anaphylactic response in TRPM4-deficient mice. 
The two molecular candidates for CAN channels identified so far are TRPM4 and TRPM5 (refs. 15,35). Only TRPM4 is expressed in BMMCs, and the lack of TRPM4 in Trpm4 ${ }^{-1-}$ mast cells was not compensated for by upregulation of TRPM5 expression. The properties of the endogenous CAN channel in BMMCs described here are very similar to the properties of TRPM4 currents recorded after overexpression of Trpm4 cDNA in HEK293 cells ${ }^{16,17,24,36}$. Both currents had identical permeability profiles and had similar single-channel conductance. The calcium sensitivity was in the same range reported for the overexpressed channel and for endogenous CAN currents in other cell types ${ }^{35}$. However, the endogenous current in BMMCs was not voltage dependent, as exemplified by the linear $I-V$ curve and low time dependence of the currents in response to 400-ms voltage steps to positive and negative membrane potentials. That is, in contrast to the electrophysiological properties of the overexpressed channel, which include channel activation at positive potentials and channel closure at negative potentials ${ }^{17}$. However, the voltage dependence of TRPM4 relies critically on phosphatidylinositol-4,5bisphosphate in the plasma membrane $e^{37,38}$; endogenous phosphatidylinositol-4,5-bisphosphate quantities might work more effectively with endogenous amounts of TRPM4 protein in primary mast cells rather than the overexpressed TRPM4 in HEK293 cells. It is notable that mice lacking type I phosphatidylinositol phosphate kinase, the enzyme that synthesizes phosphatidylinositol-4,5-bisphosphate, have greater mast cell degranulation similar to that of $\operatorname{Trpm} 4^{-/-}$mice ${ }^{39}$.

FceRI-induced mast cell activation is critically dependent on $\mathrm{Ca}^{2+}$ influx from the extracellular medium, and this influx was increased in Trpm $4^{-1-}$ mast cells. Our data showed that TRPM4 regulates FceRIinduced $\mathrm{Ca}^{2+}$ entry and mast cell activation solely through its effect on the membrane potential. There was no apparent difference in FceRItriggered activation phospholipase $\mathrm{C}-\gamma$ or phosphorylation of Akt and p38 in Trpm $4^{+/+}$and Trpm $4^{-/-}$BMMCs, and the activity of the $\mathrm{Ca}^{2+}$ influx channel (and calcium-activated potassium and chloride channels) was not different in Trpm $4^{+/+}$and Trpm $m 4^{-/-}$BMMCs. Furthermore, when membrane potential changes were prevented by FceRI stimulation in medium with a high $\mathrm{K}^{+}$concentration, $\operatorname{Trpm} 4^{+/+}$and Trpm $4^{-/-}$had similar $\mathrm{Ca}^{2+}$ signaling and mediator release. We also found increased $\mathrm{Ca}^{2+}$ influx and mediator release from Trpm4 $4^{-1-}$ BMMCs when we treated cells with $\mathrm{BH}$ or ionomycin, compounds that increased $\left[\mathrm{Ca}^{2+}\right]_{c y t}$ independently of cell stimulation. Simultaneous recording of membrane potential and $\left[\mathrm{Ca}^{2+}\right]_{\mathrm{cyt}}$ in $\operatorname{Trpm} 4^{+/+}$ BMMCs showed that FceRI stimulation led to rapid hyperpolarization followed by sustained depolarization. Changes in $\left[\mathrm{Ca}^{2+}\right]_{\mathrm{cyt}}$ occurred with similar kinetics, suggesting that FceRI-induced $\left[\mathrm{Ca}^{2+}\right]_{\text {cyt }}$ fluctuations are critically determined by $\mathrm{Ca}^{2+}$ influx and membrane potential. In contrast, Trpm $4^{-/-}$BMMCs lacked the sustained depolarization phase and, consequently, had on average a much more hyperpolarized membrane potential after receptor activation, as well as enhanced $\mathrm{Ca}^{2+}$ influx.

In our view, FceRI-mediated depletion of intracellular $\mathrm{Ca}^{2+}$ stores increases $\mathrm{Ca}^{2+}$ influx from the extracellular medium; the resulting increase in $\left[\mathrm{Ca}^{2+}\right]_{\text {cyt }}$ activates the intermediate-conductance-type calcium-activated potassium channel (also called SK4) ${ }^{27,40}$. Notably, 1-ethyl-2-benzimidazolinone (1-EBIO) which elicits opening of the intermediate-conductance calcium-activated potassium channel, enhances FceRI-dependent $\mathrm{Ca}^{2+}$ influx and mast cell degranulation ${ }^{40}$. The resulting hyperpolarization of membrane potential due to the $\mathrm{K}^{+}$ current and the activation of store-operated $\mathrm{Ca}^{2+}$ entry channels further increases $\left[\mathrm{Ca}^{2+}\right]_{\mathrm{cyt}}$, leading to the activation of a CAN current through TRPM4 channels, which depolarizes membrane potential and limits the driving force for $\mathrm{Ca}^{2+}$ entry through CRAC channels.
TRPM4 thus acts as a molecular 'brake' on $\mathrm{Ca}^{2+}$ influx after FceRIinduced activation.

A function for TRPM4 as a regulator of membrane potential in cell lines has been suggested by RNA interference and antisense 'geneknockdown' strategies ${ }^{20,21,41}$. It has been proposed that suppression of TRPM4 expression converts oscillatory changes in $\left[\mathrm{Ca}^{2+}\right]_{\text {cyt }}$ into longlasting, sustained increases in $\left[\mathrm{Ca}^{2+}\right]_{\text {cyt }}$ in a Jurkat $\mathrm{T}$ cell line ${ }^{21}$. However, many Trpm $4^{-1-}$ BMMCs showed oscillations in membrane potential, indicating that TRPM4 is not essential for the occurrence of $\mathrm{Ca}^{2+}$ oscillations. The mechanism underlying the oscillations noted in Trpm4 ${ }^{-1-}$ BMMCs is unclear at present. It has been proposed in other cell types that $\mathrm{Ca}^{2+}$ oscillations could be caused by interaction of calcium-dependent activation and 'rundown' of the intermediateconductance calcium-activated potassium channel ${ }^{42}$, or by a rhythmic activity of calcium-activated potassium channels and calciumactivated chloride channels or $\mathrm{Ca}^{2+}$ influx channels ${ }^{43}$.

After FceRI aggregation, several 'downstream' pathways elicit the release of preformed vasoactive amines, such as histamine, and the de novo synthesis of lipid-derived mediators and a range of cytokines and chemokines. We found that Trpm $4^{-1-}$ BMMCs released more histamine and leukotrienes. Such a result might be expected, because degranulation of mast cells is a calcium-activated process ${ }^{6}$ and cytosolic phospholipase $\mathrm{A}_{2}$ and 5-lipoxygenase, key enzymes required for leukotriene synthesis, are calcium sensitive ${ }^{44}$. However, secretion of TNF but not IL- 6 was higher in Trpm $4^{-1-}$ BMMCs. TNF is released from preformed vesicles ${ }^{34}$ and, as with IL-6, the gene encoding TNF is controlled by specific transcription factors ${ }^{2}$. The different effects of Trpm4 deficiency on the secretion of TNF and IL- 6 suggest that the synthesis and/or release of TNF and IL- 6 are/is probably mediated through separate mechanisms in mast cells and might be regulated by different transcription factors.

The functional importance of TRPM4 in mast cells became apparent when we induced a cutaneous allergic reaction in a PCA model that is dependent mainly on the activation of tissue mast cells in the $\operatorname{skin}^{32}$. Notably, the absence of functional TRPM4 protein had no effect on the development or density of mast cells. In response to antigen stimulation, Trpm $4^{-1-}$ mice showed considerably more fluid extravasation in tissue than did $\operatorname{Trpm} 4^{+/+}$mice. These data indicated Trpm $4^{-1-}$ mice had more vessel permeability, probably due to more histamine release from mast cells in the skin. Notably, given that TRPM4 activity is decreased by lowering the temperature ${ }^{45}$, the increased histamine release in response to cold, which can lead to cold urticaria ${ }^{46}$, might also be a demonstration of the function of TRPM4 channel activity as a molecular 'brake' on mast cell activation. In contrast to the immediate-type allergic reaction, the late-phase reaction to an allergic stimulus was not different in $\operatorname{Trpm} 4^{+/+}$versus Trpm $4^{-1-}$ mice. The reason for this was probably that the secretion of at least some mast cell-derived mediators essential for the development of the late-phase anaphylaxis reaction, such as IL-6 (ref. 47), was not influenced by Trpm4 deficiency.

In conclusion, TRPM4 functions as a calcium-activated cation channel in mast cells and thus serves as an inhibitor of mast cell activation. When TRPM4 is activated, $\mathrm{Ca}^{2+}$ influx is suppressed and the release of proinflammatory mediators is constrained. Our results establish Trpm4 as a gene involved in hypersensitivity reactions and suggest that TRPM4-activating compounds would limit the activation of mast cells and could have potential as drugs treating allergic reactions. Thus, the TRPM4-deficient mouse model could provide clues for new therapeutic strategies for treating allergic and hypersensitivity reactions, which affect more than 100 million people worldwide ${ }^{48}$. 


\section{METHODS}

Trpm4 targeting. Gene targeting in R1 embryonic stem cells and Cre-loxPmediated recombination was used to generate a mouse line with a null allele $\left(\operatorname{Trpm} 4^{--}\right)$. Additional details are in the Supplementary Methods online.

Bone marrow isolation and mast cell differentiation. Mouse BMMCs were isolated and differentiated as described ${ }^{49}$. Experiments used BMMCs maintained in culture for 5-15 weeks. For sensitization of mast cells to DNP-HSA (30-40 moles of DNP per mole albumin; Sigma), cells were incubated overnight with $300 \mathrm{ng} / \mathrm{ml}$ of IgE anti-DNP-HSA in standard culture medium. 긍 Additional information is in the Supplementary Methods online.

Solutions. The standard extracellular solution for patch-clamp and $\mathrm{Ca}^{2+}$ imaging contained $156 \mathrm{mM} \mathrm{NaCl}, 1.5 \mathrm{mM} \mathrm{CaCl}, 1 \mathrm{mM} \mathrm{MgCl}_{2}, 10 \mathrm{mM}$ glucose, $10 \mathrm{mM}$ HEPES, $\mathrm{pH}$ 7.4, with $\mathrm{NaOH}$. The pipette solution for wholecell measurements contained $20 \mathrm{mM} \mathrm{NaCl}, 100 \mathrm{mM} \mathrm{NaAsp}, 1 \mathrm{mM} \mathrm{MgCl}$, $10 \mathrm{mM}$ HEPES, pH 7.2, with $\mathrm{NaOH}$. The external solution for 'inside-out' experiments contained $156 \mathrm{mM} \mathrm{NaCl}, 1.5 \mathrm{mM} \mathrm{CaCl}_{2}, 1 \mathrm{mM} \mathrm{MgCl}_{2}, 10 \mathrm{mM}$ HEPES, pH 7.4, with $\mathrm{NaOH}$. The bath solution (cytosolic side) for 'inside-out' experiments contained $150 \mathrm{mM} \mathrm{NaCl}, 1 \mathrm{mM} \mathrm{MgCl} 2,10 \mathrm{mM}$ HEPES, $\mathrm{pH}$ 7.2, with $\mathrm{NaOH}$. Potassium was omitted from the solutions described above to avoid the contribution of $\mathrm{K}^{+}$currents. In both whole-cell and 'inside-out' studies, the $\mathrm{Ca}^{2+}$ concentration at the inner side of the membrane was adjusted between $100 \mathrm{nM}$ and $1 \mu \mathrm{M}$ by the addition of $\mathrm{CaCl}_{2}$ to $5 \mathrm{mM}$ EGTA as calculated by the CaBuf program (ftp://ftp.cc.kuleuven.ac.be/pub/droogmans/ cabuf.zip). For higher $\mathrm{Ca}^{2+}$ concentrations, $\mathrm{CaCl}_{2}$ was added to an EGTA-free solution. For current-clamp measurements, the pipette solution was $55 \mathrm{mM}$ $\mathrm{KCl}, 75 \mathrm{mM} \mathrm{K}_{2} \mathrm{SO}_{4}, 5 \mathrm{mM} \mathrm{MgCl}_{2}, 5 \mathrm{mM}$ glucose and $10 \mathrm{mM}$ HEPES, pH 7.2. For histamine release, KRH buffer was used $(130 \mathrm{mM} \mathrm{NaCl}, 4.75 \mathrm{mM} \mathrm{KCl}$, $1.2 \mathrm{mM} \mathrm{KH}_{2} \mathrm{PO}_{4}, 1.2 \mathrm{mM} \mathrm{MgSO}, 11 \mathrm{mM}$ glucose, $10 \mathrm{mM}$ HEPES and $2.54 \mathrm{mM} \mathrm{CaCl}_{2}, \mathrm{pH}$ 7.4). All chemicals were purchased from Sigma.

Electrophysiology and caclium imaging. Currents were measured in the whole-cell or 'inside-out' configuration. Step protocols consisted of a 400-ms step to $-100 \mathrm{mV}$ (holding potential, $V_{\mathrm{H}}$, is $0 \mathrm{mV}$ ), followed by a 250 -ms step to $+100 \mathrm{mV}$ applied at $0.5 \mathrm{~Hz}$. The ramp protocol consisted of a $400-\mathrm{ms}$ ramp from $-100 \mathrm{mV}$ to $+100 \mathrm{mV}\left(V_{\mathrm{H}}\right.$ is $\left.0 \mathrm{mV}\right)$, also applied at $0.5 \mathrm{~Hz}$. $\left[\mathrm{Ca}^{2+}\right]_{\mathrm{cyt}}$ was measured as described ${ }^{50}$. Data at time points after $3 \mathrm{~h}$ and $6 \mathrm{~h}$ of stimulation were obtained by loading of $1 \times 10^{6}$ cells with the caclium-sensitive dye Fura-2, AM, as described above, and were measured in an Aminco-Bowman (2) luminescence spectrometer. Electrophysiological experiments were done at 22-25 ${ }^{\circ} \mathrm{C}$. $\mathrm{Ca}^{2+}$ imaging was done at $37{ }^{\circ} \mathrm{C}$. Additional details are in the Supplementary Methods.

Mast cell mediator release. Histamine release from mast cells was determined with the $O$-phthaldialdehyde assay ${ }^{51}$. Release of IL-6 and TNF was measured with ELISA DuoSet kits (R\&D Systems); release of leukotrienes $C_{4}, D_{4}$ and $\mathrm{E}_{4}$ was measured by enzyme-linked immunoassay (GE Healthcare) according to the manufacturer's guidelines. Additional details are in the Supplementary Methods.

PCA. The protocol for immediate-phase PCA was adapted from a published protocol $^{52}$. IgE anti-DNP-HSA (30 or $60 \mathrm{ng}$ ) in $30 \mu \mathrm{l} 0.9 \%$ (weight/volume) $\mathrm{NaCl}$ was injected intradermally at two sites in the dorsal skin of 2- to 4-month-old mice under isoflurane (1.5\%) narcosis. At a third site, only an injection wound was applied ('sham'). At $48 \mathrm{~h}$ after injection of IgE anti-DNPHSA, $100 \mu \mathrm{g}$ DNP-HSA in $200 \mu \mathrm{l}$ of $0.1 \%$ (weight/volume) Evans blue dye in nonpyrogenic $0.9 \%$ (weight/volume) $\mathrm{NaCl}$ solution was injected intravenously through the retrobulbar plexus in mice under isoflurane narcosis. In control mice, nonpyrogenic $0.9 \%$ (weight/volume) $\mathrm{NaCl}$ was injected instead of IgE anti-DNP-HSA. At $1 \mathrm{~h}$ after DNP-HSA injection, mice were killed by cervical dislocation and skin biopsies around the injection site were obtained with a biopsy punch $\left(8 \mathrm{~mm}\right.$ in diameter). Biopsies were incubated for $48 \mathrm{~h}$ at $55^{\circ} \mathrm{C}$ in $500 \mu \mathrm{l}$ formamide for extraction of Evans blue dye. Extravasation of Evans blue was quantified by absorbance measurements at $620 \mathrm{~nm}$. For background subtraction, absorbance measurements at $620 \mathrm{~nm}$ from sham-injected sites were subtracted from absorbance measurements at $620 \mathrm{~nm}$ from IgE-injected sites. Late-phase PCA was assessed as described ${ }^{33}$. Mice were passively sensitized by intravenous injection of $2 \mu \mathrm{g}$ IgE anti-DNP-HSA (clone SPE-7; Sigma). At $24 \mathrm{~h}$ after sensitization, a cutaneous reaction was elicited by the application of $10 \mu \mathrm{l}$ of a solution of $0.3 \%$ (weight/volume) DNFB acetone-sunflower oil to both sides of the right ear. The cutaneous reaction was assessed by measurement of ear thickness with a micrometer at $1-48 \mathrm{~h}$ after antigen application. The untreated left ear served as control. Increase in ear thickness is expressed as the percentage of the baseline value obtained before antigen challenge. All animal experiments were done with the approval by the local government, in accordance with German legislation on the protection of animals and the National Institute of Health Guide for the Care and Use of Laboratory Animals.

Additional methods. Information on RNA blot and immunoblot analysis, immunostaining, electron microscopy, histology, lymphocyte isolation, RTPCR and insulin-secretion and glucose-tolerance tests is available in the Supplementary Methods.

Data analysis. Electrophysiological data were analyzed with WinASCD software (ftp://ftp.cc.kuleuven.ac.be/pub/droogmans/winascd.zip). Pooled data are presented as mean \pm s.e.m. of $n$ independent experiments, unless otherwise stated. The Origin 7.0 software (OriginLab) was used for statistical analysis. Significance was assessed with the two-sample Student's $t$-test $(P<0.05$ for significance). Throughout, $n$ indicates the number of individual experiments, unless otherwise stated.

Note: Supplementary information is available on the Nature Immunology website.

\section{ACKNOWLEDGMENTS}

We thank S. Collins, R. Ramracheya and P. Rorsman for measuring insulin release from pancreatic islets; $\mathrm{M}$. Thomas, M. Wymann, G. Opdenakker and T. Voets for discussions and for help with capacitance measurements (T.V.) and the PCA protocol (M.T. and M.W.); and J. Prenen, E. Martens, S. Buchholz, K. Fischer and C. Wesely for technical assistance. Supported by the Deutsche Forschungsgemeinschaft (M.F., S.P. and V.F.), Fonds der Chemischen Industrie and Sander-Stiftung (V.F.), Forschungsausschuss der Universität des Saarlandes (M.F., V.F.), the Human Frontiers Science Programme (RGP 32/2004 to R.V. and B.N.), the Belgian and Flemish Federal Government (GOA 2004/07, F.W.O., G.0136.00, F.W.O., G.0172.03 and IUAP Nr.3P4/23; Excellentiefinanciering EF/95/010 to R.V. and B.N.), the Flemish fund of scientific research (FWO-Vlaanderen; R.V.) and the Alexander von Humboldt-Stiftung (R.V.).

\section{AUTHOR CONTRIBUTIONS}

R.V., M.F., B.N. and V.F. contributed to all aspects of the manuscript (conceptual design, experimentation, mouse work, writing); J.O. contributed to gene targeting; M.M. to contributed protein chemistry; F.S. and P.W. contributed to morphological characterization of BMMCs; W.B. contributed to histology, immunocytochemistry, immunohistochemistry and electron microscopy, I.M. contributed to anaphylaxis and glucose tolerance experiments; and S.E.P. performed cell-sorting and RT-PCR of B and T cells.

\section{COMPETING INTERESTS STATEMENT}

The authors declare that they have no competing financial interests.

Published online at http://www.nature.com/natureimmunology/ Reprints and permissions information is available online at http://npg.nature.com/ reprintsandpermissions

1. Galli, S.J., Nakae, S. \& Tsai, M. Mast cells in the development of adaptive immune responses. Nat. Immunol. 6, 135-142 (2005).

2. Metcalfe, D.D., Baram, D. \& Mekori, Y.A. Mast cells. Physiol. Rev. 77, 1033-1079 (1997).

3. Ali, H., Cunha-Melo, J.R., Saul, W.F. \& Beaven, M.A. Activation of phospholipase C via adenosine receptors provides synergistic signals for secretion in antigen-stimulated RBL-2H3 cells. Evidence for a novel adenosine receptor. J. Biol. Chem. 265, 745-753 (1990).

4. Ramkumar, V., Stiles, G.L., Beaven, M.A. \& Ali, H. The A3 adenosine receptor is the unique adenosine receptor which facilitates release of allergic mediators in mast cells. J. Biol. Chem. 268, 16887-16890 (1993).

5. Gilfillan, A.M. \& Tkaczyk, C. Integrated signalling pathways for mast-cell activation. Nat. Rev. Immunol. 6, 218-230 (2006).

6. Blank, U. \& Rivera, J. The ins and outs of IgE-dependent mast-cell exocytosis. Trends Immunol. 25, 266-273 (2004).

7. Jacobson, K.A. \& Gao, Z.G. Adenosine receptors as therapeutic targets. Nat. Rev. Drug Discov. 5, 247-264 (2006). 
8. Wymann, M.P. et al. Phosphoinositide 3-kinase $\gamma$ : a key modulator in inflammation and allergy. Biochem. Soc. Trans. 31, 275-280 (2003).

9. Ozawa, K. et al. $\mathrm{Ca}^{2+}$-dependent and $\mathrm{Ca}^{2+}$-independent isozymes of protein kinase $\mathrm{C}$ mediate exocytosis in antigen-stimulated rat basophilic RBL-2H3 cells. Reconstitution of secretory responses with $\mathrm{Ca}^{2+}$ and purified isozymes in washed permeabilized cells. J. Biol. Chem. 268, 1749-1756 (1993).

10. Beaven, M.A., Moore, J.P., Smith, G.A., Hesketh, T.R. \& Metcalfe, J.C. The calcium signal and phosphatidylinositol breakdown in $2 \mathrm{H} 3$ cells. J. Biol. Chem. 259, 7137-7142 (1984)

11. Hoth, M. \& Penner, R. Depletion of intracellular calcium stores activates a calcium current in mast cells. Nature 355, 353-356 (1992).

12. Mohr, F.C. \& Fewtrell, C. Depolarization of rat basophilic leukemia cells inhibits calcium uptake and exocytosis. J. Cell Biol. 104, 783-792 (1987).

13. Mohr, F.C. \& Fewtrell, C. IgE receptor-mediated depolarization of rat basophilic leukemia cells measured with the fluorescent probe bis-oxonol. J. Immunol. 138, 1564-1570 (1987).

14. Colquhoun, D., Neher, E., Reuter, H. \& Stevens, C.F. Inward current channels activated by intracellular Ca in cultured cardiac cells. Nature 294, 752-754 (1981).

15. Prawitt, D. et al. TRPM5 is a transient $\mathrm{Ca}^{2+}$-activated cation channel responding to rapid changes in $\left[\mathrm{Ca}^{2+}\right]_{i}$. Proc. Natl. Acad. Sci. USA 100, 15166-15171 (2003).

16. Launay, P. et al. TRPM4 is a $\mathrm{Ca}^{2+}$-activated nonselective cation channel mediating cell membrane depolarization. Cell 109, 397-407 (2002).

17. Nilius, B. et al. Voltage dependence of the $\mathrm{Ca}^{2+}$-activated cation channel TRPM4. J. Biol. Chem. 278, 30813-30820 (2003)

18. Ramsey, I.S., Delling, M. \& Clapham, D.E. An introduction to TRP channels. Annu. Rev. Physiol. 68, 619-647 (2006).

19. Petersen, O.H. Cation channels: homing in on the elusive CAN channels. Curr. Biol. 12 , R520-R522 (2002).

20. Cheng, H. et al. TRPM4 controls insulin secretion in pancreatic $\beta$-cells. Cell Calcium 41, 51-61 (2007).

21. Launay, P. et al. TRPM4 regulates calcium oscillations after T cell activation. Science 306, 1374-1377 (2004).

22. Hamill, O.P., Marty, A., Neher, E., Sakmann, B. \& Sigworth, F.J. Improved patch-clamp techniques for high-resolution current recording from cells and cell-free membrane patches. Pflügers Archiv Eur. J. Physiol. 391, 85-100 (1981).

23. Hille, B. Ionic Channels of Excitable Membranes (Sinauer Associates, Sunderland, Massachusetts, 2001).

24. Nilius, B. et al. The selectivity filter of the cation channel TRPM4. J. Biol. Chem. 280, 22899-22906 (2005).

25. Salvatore, C. et al. Disruption of the $A(3)$ adenosine receptor gene in mice and its effect on stimulated inflammatory cells. J. Biol. Chem. 275, 4429-4434 (2000).

26. Marquardt, D., Walker, L. \& Wasserman, S. Adenosine receptors on mouse bone marrow-derived mast cells: functional significance and regulation by aminophylline. J. Immunol. 133, 932-937 (1984).

27. Duffy, S.M., Lawley, W.J., Conley, E.C. \& Bradding, P. Resting and activation-dependent ion channels in human mast cells. J. Immunol. 167, 4261-4270 (2001).

28. Fernandez, J.M., Neher, E. \& Gomperts, B.D. Capacitance measurements reveal stepwise fusion events in degranulating mast cells. Nature 312, 453-455 (1984).

29. Lindau, M. \& Neher, E. Patch-clamp techniques for time-resolved capacitance measurements in single cells. Pflugers Arch. 411, 137-146 (1988).

30. Marshall, J.S. Mast-cell responses to pathogens. Nat. Rev. Immunol. 4, 787-799 (2004)
31. Qiao, H., Andrade, M.V., Lisboa, F.A., Morgan, K. \& Beaven, M.A. FceR1 and Toll-like receptors mediate synergistic signals to markedly augment production of inflammatory cytokines in murine mast cells. Blood 107, 610-618 (2006).

32. Inagaki, N., Goto, S., Nagai, H. \& Koda, A. Homologous passive cutaneous anaphylaxis in various strains of mice. Int. Arch. Allergy Appl. Immunol. 81, 58-62 (1986).

33. Klemm, S. et al. The Bcl10-Malt1 complex segregates FceRI-mediated nuclear factor $\kappa \mathrm{B}$ activation and cytokine production from mast cell degranulation. J. Exp. Med. 203, 337-347 (2006)

34. Wershil, B.K., Wang, Z.S., Gordon, J.R. \& Galli, S.J. Recruitment of neutrophils during IgE-dependent cutaneous late phase reactions in the mouse is mast cell-dependent. Partial inhibition of the reaction with antiserum against tumor necrosis factor- $\alpha$. J. Clin. Invest. 87, 446-453 (1991).

35. Nilius, B. \& Vennekens, R. From cardiac cation channels to the molecular dissection of the transient receptor potential channel TRPM4. Pflugers Arch. 453, 313-321 (2006).

36. Nilius, B. et al. Regulation of the $\mathrm{Ca}^{2+}$ sensitivity of the nonselective cation channe TRPM4. J. Biol. Chem. 280, 6423-6433 (2005).

37. Nilius, B. et al. The $\mathrm{Ca}^{2+}$-activated cation channel TRPM4 is regulated by phosphatidylinositol 4,5-biphosphate. EMBO J. 25, 467-478 (2006).

38. Zhang, Z., Okawa, H., Wang, Y. \& Liman, E.R. Phosphatidylinositol 4,5-bisphosphate rescues TRPM4 channels from desensitization. J. Biol. Chem. 280, 39185-39192 (2005).

39. Sasaki, J. et al. Regulation of anaphylactic responses by phosphatidylinositol phosphate kinase type I $\alpha$. J. Exp. Med. 201, 859-870 (2005).

40. Duffy, S.M. et al. The $\mathrm{K}^{+}$channel iKCA1 potentiates $\mathrm{Ca}^{2+}$ influx and degranulation in human lung mast cells. J. Allergy Clin. Immunol. 114, 66-72 (2004).

41. Earley, S., Waldron, B.J. \& Brayden, J.E. Critical role for transient receptor potential channel TRPM4 in myogenic constriction of cerebral arteries. Circ. Res. 95, 922-929 (2004).

42. Fioretti, B., Franciolini, F. \& Catacuzzeno, L. A model of intracellular $\mathrm{Ca}^{2+}$ oscillations based on the activity of the intermediate-conductance $\mathrm{Ca}^{2+}$-activated $\mathrm{K}^{+}$channels. Biophys. Chem. 113, 17-23 (2005).

43. Lewis, R. Calcium signaling mechanisms in T lymphocytes. Annu. Rev. Immunol. 19, 497-521 (2001).

44. Peters-Golden, M., Canetti, C., Mancuso, P. \& Coffey, M.J. Leukotrienes: underappreciated mediators of innate immune responses. J. Immunol. 174, 589-594 (2005).

45. Talavera, K. et al. Heat activation of TRPM5 underlies thermal sensitivity of sweet taste. Nature 438, 1022-1025 (2005).

46. Kaplan, A.P., Garofalo, J., Sigler, R. \& Hauber, T. Idiopathic cold urticaria: in vitro demonstration of histamine release upon challenge of skin biopsies. N. Engl. J. Med. 305, 1074-1077 (1981)

47. Nagai, $\mathrm{H}$. et al. Role of mast cells in the onset of IgE-mediated late-phase cutaneous response in mice. J. Allergy Clin. Immunol. 106, S91-S98 (2000).

48. AAAAI. The Allergy Report (The American Academy of Allergy, Asthma and Immunology, Milwaukee, Wisconsin, USA, 2000).

49. Laffargue, M. et al. Phosphoinositide 3-kinase $\gamma$ is an essential amplifier of mast cell function. Immunity 16, 441-451 (2002).

50. Vriens, J. et al. Cell swelling, heat, and chemical agonists use distinct pathways for the activation of the cation channel TRPV4. Proc. Natl. Acad. Sci. USA 101, 396-401 (2004).

51. Yoshimura, T., Kaneuchi, T., Miura, T. \& Kimura, M. Kinetic analysis of the fluorescence reaction of histamine with orthophthalaldehyde. Anal. Biochem. 164, 132-137 (1987).

52. Ali, K. et al. Essential role for the p110 phosphoinositide 3-kinase in the allergic response. Nature 431, 1007-1011 (2004). 